\title{
Pluralism, Unity or Uniqueness in Labour Unions? A Historical Digression through the Political Discourses Around the Single Union Law
}

\author{
Virgílio Amaral
}

Centro de Estudos Sociais, Coimbra University; Email: virgilio.amaral@gmail.com

Doi:10.5901/ajis.2015.v4n3s1p242

\section{Abstract}

The current study follows a historical perspective to analyse the partisan positions and contents of the political discourses around the Single Union Law in Portugal, which was put forward in the revolutionary context that followed the 25th April 1974 revolution. It was enacted in 1975 and led to the first major dissent among the left-wing parties, namely the PS (Socialist Party), the PCP (Portuguese Communist Party) and their respective allies. The identification of the most controversial discourses was done using publications on the history of labour unionism under the perspective of the CGTP - General Confederation of Portuguese Workers (report entitled "Contributions towards the history of labour and trade union movement. From its roots to 1977" - Silva et al., 2011) and the UGT - General Workers Union (Brito \& Rodrigues, 2013), the two labour union federations in Portugal. The results are discussed in the conclusion, as well as the influence of labour unionism in the current times of crisis.

Keywords: Portugal, 25th April 1974 Revolution; Unions; Single Union Law; political discourses.

\section{Introduction}

Labour relations in Portugal have undergone significant changes. The conquest and gradual consolidation of the democratic regime after the 25th April 1974 revolution have brought radical changes versus the previous situation - the fascist regime. This happened right from the beginning and specifically in terms of union freedom and the right to strike, free collective negotiation, workers' participation and workers' representative structures (i.e., trade union associations and workers commissions) in the life of organisations, activity sectors and the economic and social system in general.

Immediately after the 25th April 1974 revolution, Intersindical (the federal union structure linked to the Portuguese Communist Party, which would later be replaced by the General Confederation of Portuguese Workers CGTP/Intersindical) conquered the union structures cited by the previous regime and demanded - and obtained - the legal enforcement of the Principle of the Union Uniqueness from political power.

By the end of the 1970s, the creation of the General Workers Union (UGT) was a consummated historic fact, with a union core fundamentally sustained by the political and unionist currents socialist and social-democrat, but equally supported by democrat-Christian unionists as well as others, with an independent profile.

This marked the end of the unionist monopoly detained by the CGTP - Intersindical Nacional. It was the famous political and doctrinal quarrel of the "trade union unity" versus "union uniqueness" that made up one of the most acute historical moments in the strict political battle fought in Portugal to introduce democracy.

Therefore, as aforementioned, the first unionist political cycle ended with the creation of the UGT.

Thus, the 1980s started with a significant alternative made up of union programmes and strategies, from which the right to difference developed between the two union organisations.

From here, there were deep consequences to the matrix of the Portuguese social system.

In fact, according to Estanque (2011):

If we take out any value judgements and especially, if we are able to avoid the trend of valuing unions as "good" and "bad" (the first as the ones one can supposedly have a dialogue with and the latter, the so-called conservatives or the ones 'at the service of...), we will be led to understand unionism's social and transformative role (both contestation and political dissent are equally valid in the social plan) and maybe then, it can be accepted that combative and movement unionism is the one that has mostly contributed - and can still contribute - towards society and progress (p. 59).

In a review of the history of unionism in Europe, Costa (2011) states that, in the fight to extend political democracy to the most unprotected classes, trade unions have developed "historical alliances with political parties at a time when 
universal suffrage was still uncommon" (p.15). The resulting heritage led to "distinct political directions, relations and divisions in unionism to our current time" (Costa, 2011, p. 15).

In Portugal, after the 25th April 1974 revolution, the great debate in the unionism arena was focused on unity, union uniqueness or union pluralism, opposing the Portuguese Communist Party (PCP) and its unionism ally (Intersindical) as well as most far-left political formations, to the Socialist Party (PS) and its ally in the Provisional Government of the time, the Democratic Popular Party (PPD), a precursor of the current Social-Democratic Party (PSD).

Costa (2011) clarifies the concepts under debate:

In a plural (pluralist) society, trade unions are legitimate representatives of workers' interests at the workplace, with the right to challenge and manage these interests. Contrary to a "unitary" vision, where unionism did not have a representative role or a role of conflict regulator, pluralism considered trade unions as an institutionalised way to regulate order and collective negotiation as the means to regulate the conflict between the employer and the employee (p. 25).

Differently to pluralism, the Marxist theory entailed that labour relations were deal with in a political perspective and were part of a class struggle.

It is in this ideological context that the draft law of the single union principle can be understood, as undertaken by Intersindical and the PCP. This principle advocated "one union for workers in the same industry and profession and a single trade union confederation" (Silva et al., 2011, p. 277). As an Intersindical proposal, it was submitted to the Second Provisional Government in August 1974, which decided to submit it to public discussion. There were worker assemblies in November and December 1974 (Silva et al., 2011) which led to the decision, by a majority, to include the Principle in the Law, with the approval of the law on the 21st of January, 1975 (Brito \& Rodrigues, 2013).

The controversy over this law, between the Socialist Party (PS) and its ally in the Provisional Government (the PPD) on the one hand and the Portuguese Communist Party (PCP) and its ally in the unionism sector (Intersindical) as well as several far-left formations, on the other hand, has culminated on a demonstration at the Labour Ministry. This was convened by Intersindical on the 14th January 1975 and allegedly counted on the participation of 300,000 demonstrators, according to the Confederation's official newspaper ("Grande manifestação Da Intersindical: 'Quem tem medo do Povo?' ", 1975; in Alavanca, 17th January 1975) followed by a rally by the opposite end of the Socialist Party, of a considerably smaller size. It is in this context that historical research enables the identification of the content of the discourses in the political controversy in question, today.

The issue of Uniqueness was indeed one of the first cracks between the political and social movements that, after the military coup, remained united around the backbone of the Armed Forces Movement's (MFA) programme, a movement that led to the overthrow of the fascist regime.

Obviously, it was recognised that union reorganisation was inevitable, considering the overrun of the fascist union structures (Brito \& Rodrigues, 2013; Silva et al., 2011).

Brito and Rodrigues (2013) advocate:

Throughout 1974, Intersindical had a position that changed as the conjuncture evolved: it never lost touch with the idea that it was essential, it did not get distracted from the production process of the new legislation, nor from its content. This explains why the great priority of constituting a "union reorganisation commission", consecrated in the July 1974 plenary, ended up diluting and why in October, upon the celebration of Intersindical's 4th anniversary, the commission had stopped assembling and had confined itself to producing a document on Unionist Structure (pp. 76-77).

However, it is worth noting that Intersindical, as the entity that almost entirely coordinated the Portuguese unionist movement, never stopped worrying about its central and regional organisational structure. On the contrary, it invested in the construction of a system of relations and standards that could permanently assure the consolidation of the organisation.

At the rally to commemorate Intersindical's 4th anniversary, which counted on the presence of the Prime Minister (Vasco Gonçalves) and the Labour Minister of the Provisional Government (Captain Costa Martins), interventions were focused on the MFA's support and the Single Union. Jerónimo de Sousa, current Secretary-General of the PCP was at the time the representative of the Metalworkers Trade Union in the Lisbon district. This union was part of Intersindical and called for the worker unity in trade unions, for the unions that integrated Intersindical.

Despite an apparent political consensus, PS and PPD, along with some small left-wing Maoist party formations, rose up against the possibility of the legal imposition of unity/uniqueness through communiqués and declarations to the media.

Marcelo Curto, in charge of the union and labour sector at PS, already considered the following, in an interview to 
the República newspaper (Curto, 1974; cf. República 2nd October 1974):

It is unacceptable that a law has to impose a single confederation. In all Western capitalist countries (England and Germany), this unity is a result of their own historical line of reasoning, not an imposition by the legislator. If unity is desirable, it has to be assured by objective circumstances in Portugal (p. 18)

\section{Study Objectives}

This study aims to address, from an historical point of view, the content of the main political discourses that opposed the contending parties, namely the PS and its ally in the Provisional Government at the time (PPD) and, on the other hand, the PCP and its ally in the unionist field (Intersindical). This is done based on published works on the history of unionism under the perspective of the CGTP (report entitled "Contributions towards the history of labour and trade union movement. From its roots to 1977" - Silva, et al., 2011) and the UGT - General Workers Union (Brito \& Rodrigues, 2013), as well as the works by Valente (2001) and Barreto (2005). The aim of this research, as a follow-up to the research by Amaral and Pereira (2014) on the polemic around the control of the media at the time of the revolution, is, first of all, to identify the social structure of the political reality of the time, especially regarding unionism and the labour world. Secondly, to revisit the past, reflect on some issues regarding the ways of intervention in the labour world and trade unions with an impact on the current times of deep crisis.

\section{Results: Confrontation in the Media at the Time of the Revolution}

In the Socialist Party, several political and union project trends converged, including the support of unity in trade unionism and the defence of Intersindical's conquest from within.

Socialist leader Marcelo Curto, in the aforementioned interview, clarified the initial position by the PS, stating that, there cannot be "trade union unity without, for instance, the independence of unions, because this will not have any significance if unions are not representative" (Curto, 1974).

Furthermore, the approval of a document by Intersindical that demanded the publication in the Law of the principle of "uniqueness at all levels in trade union organisations" and not just at the level of general confederation ("Unidade, a vontade dos trabalhadores", 1974, p. 1; cf. Alavanca, 9th December, 1974) helped feed further controversy around unity or union uniqueness.

In response to Carlos Carvalhas, Secretary of State of Labour at a time when he had defended the consecration of unity in the law in a statement to public television, the then minister of justice, Salgado Zenha, told the Diário de Notícias newspaper "The union government bill imposes a single union confederation. Now, and with the due respect for the opposing opinion, I consider this provision as unconstitutional" (Zenha, 1975, p. 7; cf Diário de Notícias, 7th January 1975). Remitting to the MFA's programme, which considered "a real constitutional bill", the PS leader stated that "the freedom of association and union freedom will be violated if a union confederation uniqueness is imposed" (Zenha, 1975, p. 7).

Under the perspective of the leader of the PS, the fact that union freedom is not recognised at the confederate level "is serious, because the Armed Forces Movement programme is a political commitment that provides the same obligations to all the democratic forces that support it" (Zenha, 1975, p. 7). The declarations by Salgado Zenha unleashed an enormous controversy in the public and political sphere.

In an article published in Diário de Notícias (13th January 1975), the communist leader Carlos Carvalhas responded, considering it unconstitutional not to approve union uniqueness and saying that this did not oppose freedom, since the law enshrined union freedom, the choice by leaders, and this enabled the establishment of "vertical unions and new associations as well as representative unions chosen by the majority" (Carvalhas, 1975, p. 7).

Stating that, what would be unconstitutional would rather be the lack of the provision of uniqueness in the law, he considered that uniqueness did not "oppose to union freedom" (Carvalhas, 1975, p. 7). According to him, the law proposal advocated union freedom, the freedom to choose the leaders and that it foresaw the inclusion of some standards "that would guide the statutes to confer them a wide internal democracy" (Carvalhas, 1975, p. 7).

The PCP (on a press release by the Political Commission, on the 13th of January, 1975) considered that, "the single union strengthens class unity, ensures the free constitution, direction and management of trade unions by workers. ... Conversely, the so-called pluralism, the proliferation of unions, would in fact oppose the freedom and independence of the trade union movement" (PCP, 1975). The PCP argued that trade union uniqueness had been widely discussed by workers and therefore, "no one in good faith can deny the overwhelming approval that it received" (PCP, 1975). 
The PCP also responded to Zenha (1975), confirming "once again, its position that, the principle of uniqueness in unions is the best assurance of union freedom in the current concrete circumstances in Portugal". According to the PCP's Political Commission (on the same press release):

\begin{abstract}
Union uniqueness strengthens class unity, assures the free constitution, direction and management of trade unions by the workers, guarantees the independence of trade unions in relation to the State, the Government, the parties and the employers. Inversely, the so-called pluralism - the proliferation of trade unions - would in fact be contrary to the freedom and independence of the trade union movement. The PCP states that is position in defence of union freedom is part of its general policy of defending democratic freedom and is integrated in the objective of establishing a democratic regime in Portugal, in which the Portuguese people enjoy the widest of freedoms and which the organisation and defence of the opinions of all the Portuguese willing to live freely and respect the democratic order.
\end{abstract}

According to the PCP, union uniqueness had already been democratically debated by the workers and thus, "no one in good faith can deny the overwhelming approval that it received". To the PCP, "the new memberships that have been constantly recorded by the popular movement" to the principle of union uniqueness have given it a free and democratic expression (PCP, 1975).

Yet, the PPD considered, on its official newspaper Povo Livre (16th January, 1975) that the law of uniqueness was oppressive and that it opposed to the freedom of association (hence the "trade union pluralism", according to this party) proclaimed in the Armed Forces Movement's programme ("Os sindicatos únicos são o caminho mais certo para 0 regresso da opressão", 1975).

Under the title "The single unions are the right path towards the return of oppression", the PPD expresses the following concerns on the law on union uniqueness, regarding the theme of "union freedom":

On the recent stands taken about union uniqueness, the PPD cannot fail to insist on the need for this uniqueness to never sacrifice union freedom. . . . Union uniqueness ... is not the result of the rule of law or of any limitations to the right of union freedom. ... It is the law ... that imposes single unions. .. The regime set up is not one of union unity, but rather one of union uniqueness, of which we had an example before the 25th April and which we can still see in the left and right-wing dictatorships ("Os sindicatos únicos são o caminho mais certo para a opressão", 1975, p. 3).

In their turn, socialist leaders Fernanda Lopes Cardoso and Marcelo Curto, on República newspaper (4th January 1975), stressed the importance of the Workers Commissions and of the bases stating that these "have acquired an undeniable importance in the Portuguese labour movement, thus constituting the expression of the long-overdue democracy" (Cardoso \& Curto, 1975, p. 3). These socialist leaders stated the following, emphasising the role of Workers Commissions and bases:

Workers Commissions have acquired an indisputable role in the Portuguese workers' movement, forming the expression of the long-awaited democracy as well as a direct and effective means of action. Indisputable, albeit contested by the union organisations with less means of control over the working class, Workers Commissions, which should logically form the starting point for the new forms of organisation have been - where unions have enough power - destroyed by all the means and neglected in favour of "Delegate Commissions", and these have often been contested by the workers themselves (Cardoso \& Curto, 1975, p. 3).

The leader of the PPD at the time, Francisco Sá Carneiro, said, in an interview to newspaper A Capital (21st January 1975), and opposing to "imposed units that limited workers' choice" (Carneiro, 1975, p.15), clarifying the positions of his party at the time:

We defend a strong unionism, because strength is efficiency; that is why we privilege unions by branch of business and not by profession. We defend a base union, where workers are the ones that decide at all levels, the ones that choose their leaders and the ones that control the action of the different components. We defend a type of unionism that is independent from the State, political parties, religious groups, economic forces or any other institution. We defend free unionism, with the exercise of freedom of association, constitution, internal organisation and management, federation and confederation and even international association. We even advocate unity in unionism that expresses the result of the exercise of freedom rather than law enforcement. (Carneiro, 1975, p. 15)

As aforementioned, Intersindical, with the support of the PCP and several far-left organisations, convened the demonstration to take place on the 14th of January of that same year, in Lisbon, in a show of force. The Minister of Labour stated, during that demonstration: "The problem is no longer uniqueness nor the war between parties. It is about 
the respect or the lack of the respect for the will of the majority" ("Grande manifestação da Intersindical: "Quem tem medo do povo?"', 1975, p. 5).

According to Varela (2011), the demonstration is "also an event that proves that part of the workers relied on the policy on union uniqueness" (p. 143). According to the same author, "the PCP wanted to convince the workers of union uniqueness, but it was talking about unity, merging in its propaganda the concept of uniqueness and unity and later, the concepts of uniqueness and democracy" (Varela, 2011, p. 143).

According to Barreto (2005), the PS "has invested all its political power and mobilising capacity in the rejection of the draft law" (p. 259) with the organisation of rallies and other initiatives against the draft law on union uniqueness. But this project would end up being approved by a majority by the Provisional Government on the 21st of January, and the law was passed.

In the opinion of Brito and Rodrigues (2013), the polemic around the law on union uniqueness led to the isolation of the PCP and Intersindical:

January 1975 market the onset of a process of loss of influence for communists in the unionist organisation that would have the defeat of the communist leadership as its high moment, in the elections to the board of the northern bankers union. ... Avelino Gonçalves, the great advocate of union uniqueness from the time he spent as the government's Minister of Labour, would ironically become the first communist leader to lose his place in the democratic elections after the 25th of April. (p. 92).

However, according to Valente (2001), most labour unions in the industry, agriculture and transportation would remain based on Intersindical.

\section{Discussion and Provisional Conclusions}

The 1974 revolution in Portugal led to major changes in the labour and trade union world. In the 1980s, we saw the creation of the new federal union, UGT, supported by the socialist and social-democrat currents. The PCP has always been consistent in the defence of a single union Confederation, and the PS, which initially defended base positions, soon changed the law on trade union uniqueness, with the support of the PPD. From early on, the PPD emphasised the issue of "union freedom" and advocated union pluralism.

According to Costa (2011) we can now identify the two federal unions - CGTP and UGT - with a unionism of contestation and negotiation, respectively. However, in the present time of crisis, according to Estanque (2011), "a profound change in the scope of labour has given rise to re-emerging problems that were supposed to have been solved for decades. ... We bear the burden of the recent past, marked by countless contrasts" (p. 55).

According to the same author, "if there was indeed fundamental progress in Europe ... the organisational skills and collective struggle of the workers would be due.... This is a heritage that has been claimed by the whole left-wing, from social-democrats to the communist movement" (Estanque, 2011, p. 56).

With the current consensus in Portugal on union pluralism, the crisis and the new inorganic labour movements (such as "Geração à Rasca", freely translated as "generation in trouble" or "Precários Inflexíveis", freely translated as "inflexible precarious workers") will require a new consensus among the various stakeholders to enable an effective unity in this fight. It seems to be necessary to find formulas for the two central trade unions, independent trade unions and inorganic movements to join vindictive dispute platforms at this time of a deep crisis, deregulation of labour and insecurity induced by neo-liberalism as well as a certain inertia in unions in Portugal.

\section{References}

Amaral, V., \& Pereira, S. (2014). O Caso República e a retórica nos discursos políticos: Um estudo descritivo. Análise Psicológica, 1 , 105-126. doi: 10.14417/ap.768.

Barreto, J. (2005). O PS e o movimento sindical. In V. Canas (Ed.), O Partido Socialista e a democracia (pp. 245-271). Oeiras: Celta Editora.

Brito, J. M., \& Rodrigues, C. (2013). A UGT na história do movimento sindical português, 1970-90. Lisboa: Tinta-da-China.

Cardoso, F. L., \& Curto, M. (1975, 4 de Janeiro). O movimento sindical português. República, pp. 3-4.

Carneiro, F. S. (1975, 21 de Janeiro). Social-democracia não mantém sistema capitalista [Interview]. A Capital, pp. 14-16.

Carvalhas, C. (1975, 13 de Janeiro). Deve respeitar-se a vontade dos trabalhadores. Diário de Notícias, p. 7.

Costa, H. A. (2011). Do enquadramento teórico do sindicalismo às respostas pragmáticas. In E. Estanque, \& H. A. Costa (Eds.), 0 sindicalismo português e a nova questão social: Crise ou renovação? (pp. 13-48). Coimbra: Almedina. 
Curto, M. (1974, 2 de Outubro). Entrevista com Marcelo Curto [Interview with Marcelo Curto]. República, pp. 17-18.

Estanque, E. (2011). Trabalho, sindicalismo e acção colectiva: Desafios num contexto de crise. In E. Estanque, \& H. A. Costa (Eds.), O Sindicalismo português e a nova questão Social: Crise ou renovação? (pp. 49-62). Coimbra: Edições Almedina.

Grande manifestação da Intersindical: "Quem tem medo do povo?". (1975, 17 de Janeiro). Alavanca, pp. 2, 4.

Os sindicatos únicos são o caminho mais certo para o regresso da opressão. (1975, 16 de Janeiro). Povo Livre, p. 3.

PCP (1975). Sobre a manifestação pela unicidade sindical - Nota da Comissão Política do Comité Central do PCP [Online]. Retrieved from: http://www.pcp.pt/joomla/index.php?option=com_content\&task=view\&id=268\&ltemid=154 (June, 10, 2015)

Silva, M., Nunes, A., Cabrita, D., Martins, E., Rocha, F., Cartaxo, J., \& Barreto, K. (2011). Contributos para a história do movimento operário e sindical. Das raízes até 1977 (Vol. 1). Lisboa: CGTP-IN / Instituto Bento de Jesus Caraça.

Unidade: A vontade dos trabalhadores (1974, 9 de Dezembro). Alavanca, pp. 1-2.

Valente, J. C. (2001). O movimento operário e sindical (1970-1976): Entre o corporativismo e a unicidade. In J. M. Brito (Ed.), 0 país e a revolução (pp. 209-251). Lisboa: Círculo de Leitores.

Varela, R. (2011). A história do PCP na Revolução dos Cravos. Lisboa: Bertrand Editora.

Zenha, F. S. (1975, 7 de Janeiro). Unidade sindical ou medo à liberdade? Diário de Notícias, p. 7. 